\title{
Yield and Economics of Mustard (Brassica compestris L.) as Influenced by Sowing Methods and Levels of Sulphur and Boron
}

\author{
Hemkalyan Verma $^{1 *}$ and Joy Dawson ${ }^{2}$ \\ ${ }^{1}$ Department of Agronomy, Palli Shiksha Bhavana, Visva-Bharati, Sriniketan, \\ Bolpur, W.B.-700 120, India \\ ${ }^{2}$ Department of Agronomy, Allahabad School of Agriculture, Sam Higginbottom University of \\ Agriculture, Technology and Sciences, Allahabad-211007, (U.P.), India \\ *Corresponding author
}

\section{A B S T R A C T}

A field experiment was conducted during the winter season of 2013-14 at the Crop Research Farm, Department of Agronomy, Allahabad School of Agriculture, SHUATS, Allahabad (U.P.) to study the "Effect of sowing methods and levels of sulphur and boron

\section{Keywords}

Boron, Sowing methods, Sulphur, Mustard

\section{Article Info}

Accepted:

04 December 2017

Available Online:

10 January 2018 on yield and economics of mustard (Brassica compestris L.) $c v$. Peela Sona.". The experiment was laid out in RBD with twelve treatments and replicated thrice. The plot consisted of three levels of sulphur $\left(15,30\right.$ and $\left.45 \mathrm{~kg} \mathrm{ha}^{-1}\right)$, two levels of boron (1 and $2 \mathrm{~kg}$ $\mathrm{ha}^{-1}$ ) with two sowing methods (line sowing and broadcasting) along with NPK each at $80: 40: 40 \mathrm{~kg} \mathrm{ha}^{-1}$ respectively, the results revealed that the maximum no. of siliquae plant ${ }^{-1}$ (144.86), no. of seeds siliqua ${ }^{-1}$ (41.60), test weight $(3.18 \mathrm{~g})$, seed yield (1.74 $\left.\mathrm{t} \mathrm{ha}^{-1}\right)$, harvest index $(41.90 \%)$ and oil content $(44.21 \%)$ in the treatment $\mathrm{T}_{5}$ (sulphur $30 \mathrm{~kg} \mathrm{ha}^{-1}$ and boron $2 \mathrm{~kg} \mathrm{ha}^{-1}$ with line sowing). The maximum total cost of cultivation (34300.68 Rs ha ${ }^{-1}$ ) in the treatment $\mathrm{T}_{6}$ and $\mathrm{T}_{12}$ (sulphur $45 \mathrm{~kg} \mathrm{ha}^{-1}$ and boron $2 \mathrm{~kg} \mathrm{ha}^{-1}$ with line sowing) and (sulphur $45 \mathrm{~kg} \mathrm{ha}^{-1}$ and boron $2 \mathrm{~kg} \mathrm{ha}^{-1}$ with broadcasting), respectively. The maximum grass return (53860 Rs ha ${ }^{-1}$ ) obtained in the treatment $\mathrm{T}_{5}$ (sulphur $30 \mathrm{~kg} \mathrm{ha}^{-1}$ and boron 2 $\mathrm{kg} \mathrm{ha}^{-1}$ with line sowing). The maximum stover yield (2.70 $\left.\mathrm{t} \mathrm{ha}^{-1}\right)$, net return (22899.32 Rs $\mathrm{ha}^{-1}$ ) and benefit cost ratio (1.82) obtained in the treatment $\mathrm{T}_{7}$ (sulphur $15 \mathrm{~kg} \mathrm{ha}^{-1}$ and boron $1 \mathrm{~kg} \mathrm{ha}^{-1}$ with broadcasting).

\section{Introduction}

Mustard (Brassica compestris L.) is important oilseed crop of family cruciferae and occupies a prominent place among oilseed crops being next to groundnut in important. The present area, production and yield of nine oilseeds in India is around $26.48 \mathrm{mha}, 30.94 \mathrm{mt}$ and 1168 $\mathrm{kg} \mathrm{ha}^{-1}$ respectively, and rapeseed mustard sown area in India is 6.36 mha which has a production of $8.03 \mathrm{mt}$. The average productivity of rapeseed mustard in India is $1262 \mathrm{~kg} \mathrm{ha}^{-1}$ (Directorate of Economics and Statistics, Department of Agriculture and Cooperation, 2012-13). The average productivity of rapeseed-mustard in India is only $1145 \mathrm{~kg} \mathrm{ha}^{-1}$, which needs to be enhanced up to $2562 \mathrm{~kg} \mathrm{ha}^{-1}$ by 2030 for ensuring edible 
oil self-reliance (DRMR, 2011). The country shares about $23 \%$ of the world production of rapeseed and mustard. These crops are of particular significance of Rajasthan and Uttar Pradesh, which shares about $80 \%$ of area and production of entire country. The oil content of the mustard seeds ranges from 35-48 \% and $37-42 \%$ protein in cake (NIIR, Board; Nagaraj, 1995). Sowing technique depends upon land resources, soil condition, and level of management and thus broadcast, line sowing, ridge and furrow method and broad bed and furrow method are common sowing techniques. At higher soil moisture regimes, broadcasting followed by light planking gives early emergence and growth. Under normal and conserved moisture regime, seed placement in moist horizon under line sowing becomes beneficial. It is well known that sulphur is only next to nitrogen in the nutrition of Brassica crops. Sulphur requirement is higher than any other crops because the synthesis of thioglucosides and other related compounds present to the extent of about $3 \%$ of plant dry weight. After N, P and K, S is the fourth nutrient, whose deficiency is wide spread in India (Sarkees, 2013). Among the nutrients, sulphur plays an important role in the biosynthesis of some metabolites, such as chlorophyll, amino acids and essential oils (Morris, 2006). Sulphur plays an important role in metabolism of rapeseed-mustard plant as a component of proteins and formation of flavouring compounds known as glucosinolates (Orlovius and Kirkby, 2013). Sulphur plays a very important role in higher protein and oil production (Jamal et al., 2006). It is an element that is not easily translocated in plant, and its deficiency may cause a significant decrease in seed yield (Jat et al., 2017; Malhi and Leach, 2002). Reports from 12 Indian state cooperative studies of TSI, FAI and IFA at national centers revealed that an average $30-35 \%$ of cropped soils were deficit in $\mathrm{S}$ and another $35 \%$ potentially deficient indicating widespread soil $\mathrm{S}$ hunger (NIIR,
Board). Recent advances in $\mathrm{B}$ research have greatly improved an understanding for B uptake and transport processes (Frommer and Von Wiren, 2002), and roles of B in cell wall formation (O'Neill et al., 2004), cellular membrane functions (Goldbach et al., 2001), and anti-oxidative defense systems. Reproductive growth, especially flowering, fruit and seed set is more sensitive to boron (B) deficiency than vegetative growth (Dear and Lipsett, 1987). Thus, B fertilization is necessary for improvement of crop yield as well as nutritional quality. There are numerous reports on the positive response of mustard to B fertilization (Hossain et al., 2011; Islam, 2005; Saha et al., 2003). Hence an attempt was made to study the effect of sowing method, S and B on yield attributes, seed yield and economics of mustard under irrigated conditions.

\section{Materials and Methods}

The experiment was carried out during winter season 2013-14 at Crop Research Farm, Department of Agronomy, Allahabad School of Agriculture, Sam Higginbottom University of Agriculture, Technology and Sciences, Allahabad (U.P.). Which is located at $25^{\circ} 24^{\prime}$ $42^{\prime \prime} \mathrm{N}$ latitude, $81^{\circ} 50^{\prime} 56^{\prime \prime} \mathrm{E}$ longitude and 98 $\mathrm{m}$ altitude above the mean sea level. This area is situated on the right side of the river Yamuna and Allahabad Rewa Road about 5 $\mathrm{km}$ away from Allahabad city. The soil was sandy loam, $\mathrm{pH}$ of soil was 7.4 with $0.39 \%$ organic $\mathrm{C}$, having available $\mathrm{N}, \mathrm{P}, \mathrm{K}(185.5,36$ and $98 \mathrm{~kg} \mathrm{ha}^{-1}$ respectively). The experiment was laid out in randomized block design (factorial) with three replications, having three factors are sowing methods (line sowing and broadcasting), sulphur levels (15, 30 and 45 $\mathrm{kg} \mathrm{ha}^{-1}$ ) and boron levels (1 and $2 \mathrm{~kg} \mathrm{ha}^{-1}$ ). Half dose of nitrogen (40 kg ha ${ }^{-1}$ ) and full dose of phosphorus and potash each $40 \mathrm{~kg} \mathrm{ha}^{-1}$ was applied basal and remaining half dose of nitrogen $\left(40 \mathrm{~kg} \mathrm{ha}^{-1}\right)$ was applied after the first 
irrigation. There were total 12 treatment combinations in all. The net subplot size was 3 $\mathrm{m} \times 3 \mathrm{~m}$. All other agronomic practices i.e. thinning, hoeing, eradication of weeds and irrigation was kept same for all treatments. Mustard variety 'Peela Sona' was sown. The line sowing was done at a spacing of $30 \times 10$ $\mathrm{cm}$. Economics of different treatments was worked out on the basis of results of siliquae and seed yield of mustard in terms of gross and net returns $\mathrm{ha}^{-1}$ and $\mathrm{B}: \mathrm{C}$ ratio considering the prevailing market price of produce and cost of cultivation.

\section{Results and Discussion}

\section{Yield attributing traits}

Yield attributing characters branches plant $^{-1}$, siliquae plant $^{-1}$, seeds siliquae ${ }^{-1}$, test weight, seed yield, oil yield, oil content percentage, stover yield and harvest index of mustard under sowing methods, sulphur and boron levels has been tabulated in the table 1 . The maximum number of branches plant ${ }^{-1}$ was 9.93 and siliquae plant ${ }^{-1}$ were 144.16 recorded in the treatment $\mathrm{T}_{5}$ (sulphur $30 \mathrm{~kg} \mathrm{ha}^{-1}+$ boron $2 \mathrm{~kg}$ $\mathrm{ha}^{-1}$ with line sowing). Branching and siliquae are basically a genetic character but environmental conditions and different sowing method may also influence the number of branches per plant and play an important role in enhancing seed yield. The $30 \mathrm{~kg} \mathrm{~S} \mathrm{ha}^{-1}$ would accelerate phenological development and improve seed quality of mustard as well as the yield contributing characters increased significantly with the increased rate of boron application up to $1.5 \mathrm{~kg} \mathrm{~B} \mathrm{ha}^{-1}$ (Hassan and Malhi, 2011; Malhi and Leach, 2002). The maximum number of seeds siliqua ${ }^{-1}$ was 41.60 and test weight was $3.18 \mathrm{~g}$ were recorded in the treatment $\mathrm{T}_{5}$ (sulphur $30 \mathrm{~kg} \mathrm{ha}^{-1}$ +boron 2 $\mathrm{kg} \mathrm{ha}^{-1}$ with line sowing). Number of seeds per siliquae is considered an important factor that directly imparts in exploiting potential yield recovery in mustard crops. The results and probable reasons for such results are in conformity with the findings (Malhi and Leach, 2002) reported that filled grains per pod were highest with $1.5 \mathrm{~kg} \mathrm{~B} \mathrm{ha}{ }^{-1}$, which was identical to $2.0 \mathrm{~kg} \mathrm{~B} \mathrm{ha}^{-1}$. The sulphur application up to $30 \mathrm{~kg} \mathrm{ha}^{-1}$ significantly improved the yield attributes (Kumar et al., 2012). The application of $30 \mathrm{~kg} \mathrm{~S} \mathrm{ha-1}$ enhanced the 1000 grain weight of beans (Kumar et al., 2012; Jat et al., 2017).

The maximum seed yield was 1.74 tha $^{-1}$ recorded in the treatment $T_{5}$ (sulphur $30 \mathrm{~kg}$ ha ${ }^{1}+$ boron $2 \mathrm{~kg} \mathrm{ha}^{-1}$ with line sowing). Dry matter production and its transformation into economic yield is the ultimate outcome of various physiological, biochemical, phenological and morphological events occurring in the plant system. Seed yield of a variety is the result of interplay of its genetic makeup and environmental factors in which plant grow. The results and probable reasons for such results are in conformity (Pavani et al., 2013) and application of $30 \mathrm{~kg} \mathrm{~S} \mathrm{ha}{ }^{-1}$ recorded highest seed yield over 0 and $15 \mathrm{~kg} \mathrm{~S}$ $\mathrm{ha}^{-1}$. The increase in seed yield of Indian mustard was significant only up to $25 \mathrm{~kg} \mathrm{P}_{2} \mathrm{O}_{5}$ $\mathrm{ha}^{-1}$ and $20 \mathrm{~kg} \mathrm{~S} \mathrm{ha}^{-1}$ and $\mathrm{B}$ : $\mathrm{C}$ ratio was the highest with $25 \mathrm{~kg} \mathrm{P}_{2} \mathrm{O}_{5}$ and $20 \mathrm{~kg} \mathrm{~S} \mathrm{ha}^{-1}$ (Rana et al., 2004). The response of Indian mustard to four levels of S $0,15,30$ and $45 \mathrm{~kg}$ $\mathrm{S}_{\mathrm{ha}}{ }^{-1}$ (Verma et al., 2011).

Among the $\mathrm{S}$ level, $45 \mathrm{~kg} \mathrm{~S}^{-1}$ being at par with $30 \mathrm{~kg} \mathrm{~S} \mathrm{ha}{ }^{-1}$ gave significantly higher seed yield. The maximum stover yield was $2.70 \mathrm{t} \mathrm{ha}^{-1}$ recorded in the treatment $\mathrm{T}_{7}$ (sulphur $30 \mathrm{~kg} \mathrm{ha}^{-1}$ +boron $1 \mathrm{~kg} \mathrm{ha}^{-1}$ with broadcasting). The effect of B application on the stover yield of mustard was not significant. However, Boron control treatment produced the lowest stover yield and application of $1 \mathrm{~kg} \mathrm{~B} \mathrm{ha}^{-1}$ got the highest (Hossain et al., 2011). The maximum oil yieldwas755.50 $\mathrm{kg} \mathrm{ha}^{-1}$ recorded in the treatment $\mathrm{T}_{5}$ (sulphur $30 \mathrm{~kg} \mathrm{ha}^{-1}+$ boron $2 \mathrm{~kg} \mathrm{ha}^{-1}$ with line sowing). The sulphur 
application upto $30 \mathrm{~kg} \mathrm{ha}^{-1}$ significantly improves the oil yield (Tomar and Singh, 2007). The drill-row sowing method produced seed and oil yields more than broadcasting method (Sarkees, 2013). The application of
$1.0 \mathrm{~kg} \mathrm{~B} \mathrm{ha}^{-1}$ significantly increased oil yields over the control (Verma et al., 2012). The maximum oil content $(44.21 \%)$ was recorded in the treatment $\mathrm{T}_{6}$ (sulphur $45 \mathrm{~kg} \mathrm{ha}^{-1}+$ boron $2 \mathrm{~kg} \mathrm{ha}^{-1}$ with line sowing).

Table.1 Yield attributing traits of mustard in sowing methods and levels of sulphur and boron

\begin{tabular}{|c|c|c|c|c|c|c|c|c|c|}
\hline Treatments & $\begin{array}{l}\text { No. of } \\
\text { branches } \\
\text { plant }^{-1}\end{array}$ & $\begin{array}{l}\text { Siliquae } \\
\text { plant }^{-1}\end{array}$ & $\begin{array}{c}\text { Seeds } \\
\text { siliquae }^{-1}\end{array}$ & $\begin{array}{c}\text { Test } \\
\text { Weight } \\
\text { (g) }\end{array}$ & $\begin{array}{l}\text { Seed } \\
\text { yield } \\
\text { (t /ha) }\end{array}$ & $\begin{array}{c}\text { Oil } \\
\text { Yield } \\
\text { kg ha }^{-1}\end{array}$ & $\begin{array}{c}\text { Oil } \\
\text { content } \\
(\%)\end{array}$ & $\begin{array}{l}\text { Stover } \\
\text { yield } \\
\text { (t /ha) }\end{array}$ & $\begin{array}{c}\text { Harvest } \\
\text { Index } \\
(\%)\end{array}$ \\
\hline$T_{1}$ & 9.20 & 142.26 & 38.80 & 2.98 & 1.59 & 681.63 & 42.87 & 2.50 & 37.66 \\
\hline$T_{2}$ & 9.40 & 143.60 & 38.90 & 2.90 & 1.67 & 721.60 & 43.21 & 2.45 & 39.80 \\
\hline$T_{3}$ & 9.46 & 142.73 & 40.46 & 2.95 & 1.63 & 711.33 & 43.64 & 2.33 & 39.95 \\
\hline$T_{4}$ & 9.33 & 140.26 & 39.80 & 2.86 & 1.64 & 706.67 & 43.09 & 2.49 & 38.97 \\
\hline$T_{5}$ & 9.93 & 144.86 & 41.60 & 3.18 & 1.74 & 755.50 & 43.42 & 2.26 & 41.90 \\
\hline$T_{6}$ & 9.80 & 138.06 & 37.66 & 3.10 & 1.65 & 729.46 & 44.21 & 2.29 & 40.98 \\
\hline$T_{7}$ & 9.26 & 137.93 & 40.60 & 2.70 & 1.60 & 658.56 & 41.16 & 2.70 & 36.77 \\
\hline $\mathrm{T}_{8}$ & 9.26 & 137.20 & 38.26 & 2.75 & 1.53 & 642.60 & 42.00 & 2.67 & 36.43 \\
\hline $\mathrm{T}_{9}$ & 9.40 & 139.93 & 38.66 & 2.76 & 1.64 & 691.91 & 42.19 & 2.64 & 37.88 \\
\hline$T_{10}$ & 9.00 & 137.00 & 37.46 & 2.72 & 1.57 & 949.66 & 41.38 & 2.68 & 36.94 \\
\hline$T_{11}$ & 9.06 & 142.73 & 39.60 & 2.80 & 1.62 & 689.14 & 42.54 & 2.63 & 37.53 \\
\hline$T_{12}$ & 9.00 & 139.80 & 38.06 & 2.84 & 1.60 & 683.04 & 42.69 & 2.63 & 37.68 \\
\hline F test & NS & NS & NS & NS & NS & NS & NS & NS & $\mathrm{S}$ \\
\hline SEd $( \pm)$ & 0.51 & 3.68 & 1.95 & 0.24 & 0.18 & 0.42 & 1.11 & 0.26 & 0.01 \\
\hline $\mathrm{CD}(p \pm 0.05)$ & - & - & - & - & - & - & - & - & 0.037 \\
\hline
\end{tabular}

Table.2 Economic traits of mustard in sowing methods and levels of sulphur and boron

\begin{tabular}{|l|c|c|c|c|}
\hline Treatments & $\begin{array}{c}\text { Total cost } \\
\text { (Rs/ha) }\end{array}$ & $\begin{array}{c}\text { Gross return } \\
\text { (Rs/ha) }\end{array}$ & $\begin{array}{c}\text { Net return } \\
\text { (Rs/ha) }\end{array}$ & B: C Ratio \\
\hline$T_{1}$ & 27800.68 & 50200 & 22239.32 & 1.80 \\
\hline$T_{2}$ & 30050.68 & 52550 & 22499.32 & 1.74 \\
\hline$T_{3}$ & 32300.68 & 51230 & 18929.32 & 1.58 \\
\hline$T_{4}$ & 29800.68 & 51690 & 21889.32 & 1.73 \\
\hline$T_{5}$ & 32050.68 & 53860 & 21809.32 & 1.68 \\
\hline$T_{6}$ & 34300.68 & 51790 & 17489.32 & 1.50 \\
\hline$T_{7}$ & 27800.68 & 50700 & 22899.32 & 1.82 \\
\hline$T_{8}$ & 30050.68 & 48570 & 18519.32 & 1.61 \\
\hline$T_{9}$ & 32300.68 & 51840 & 19539.32 & 1.60 \\
\hline$T_{10}$ & 29800.68 & 49780 & 19979.32 & 1.67 \\
\hline$T_{11}$ & 32050.68 & 51230 & 19179.32 & 1.59 \\
\hline$T_{12}$ & 34300.68 & 50630 & 16329.32 & 1.47 \\
\hline
\end{tabular}




\section{Economic traits}

Economics viz., cost of cultivation, gross return, net return and benefit cost ratio of mustard under sowing methods, sulphur and boron levels have been tabulated in table 2 . Returns were calculated from the market price of seeds Rs $3000 \mathrm{q}^{-1}$ and stover Rs $100 \mathrm{~kg}^{-1}$ of Mustard. The variable cost was calculated from the fertilizer application cost which worked out to be Rs $120 \mathrm{~kg}^{-1} \mathrm{~S}$ and Rs 400 $\mathrm{kg}^{-1}$ boron.

Among the treatments $\mathrm{T}_{6}(45 \mathrm{~kg}$ sulphur and $2 \mathrm{~kg}$ boron ha ${ }^{-1}$ with line sowing) and $\mathrm{T}_{12}(45$ $\mathrm{kg}$ sulphur and $2 \mathrm{~kg}$ boron $\mathrm{ha}^{-1}$ with broadcasting) maximum total cost of cultivation $\left(34300 \mathrm{Fha}^{-1}\right)$ were recorded, whereas gross return was highest (53860₹ $\mathrm{ha}^{-1}$ ) with treatment $\mathrm{T}_{5}(30 \mathrm{~kg}$ sulphur and 2 $\mathrm{kg}$ boron $\mathrm{ha}^{-1}$ with line sowing). However, maximum net returns $\left(22499.32 \mathrm{Fha}^{-1}\right)$ and highest $\mathrm{B}$ : $\mathrm{C}$ ratio (1.82) was recorded with treatment $\mathrm{T}_{2}(30 \mathrm{~kg}$ sulphur and $1 \mathrm{~kg}$ boron $\mathrm{ha}^{-1}$ with line sowing) and $\mathrm{T}_{7}(15 \mathrm{~kg}$ sulphur and $1 \mathrm{~kg}$ boron $\mathrm{ha}^{-1}$ with broadcasting), respectively. Boron application was superior to the control for net returns and $\mathrm{B}$ : $\mathrm{C}$ ratio. Such behaviour of economic parameters due to $\mathrm{S}$ and $\mathrm{B}$ levels was due to changes in marginal seed yield of the crop with successive increase in fertilizer nutrient and relative costs of inputs in relation to output. The application of $60 \mathrm{~kg} \mathrm{~S} h a^{-1}$ and $1.0 \mathrm{~kg} \mathrm{~B}$ $\mathrm{ha}^{-1}$ significantly increased seed yield, economics and oil yield over the control (Verma et al., 2012). The cost effective economically optimum dose of sulphur for sunflower cultivation was found to be 36.70 $\mathrm{kg} \mathrm{S} \mathrm{ha}{ }^{-1}$ under its full availability (Sheoran et al., 2013).

The application of Sulphur at $30 \mathrm{~kg} \mathrm{ha}^{-1}$ and Boron at $2 \mathrm{~kg} \mathrm{ha}^{-1}$ along with recommended dose of nutrients $\left(\mathrm{N}\right.$ at $80, \mathrm{P}_{2} \mathrm{O}_{5}$ at 40 and $\mathrm{K}_{2} \mathrm{O}$ at $40 \mathrm{~kg} \mathrm{ha}^{-1}$ ) with line sowing recorded highest yield with Non-significant results. Since the data is based on the study concluded in one season, the experiment may be repeated to confirm the findings.

\section{References}

Dear, B.S., and Lipsett, J., 1987. The effect of boron supply on the growth and seed production of subterranean clover (Trifolium subterraneum L.) Australian Journal of Agriculture Research, 38, $537-546$.

Directorate of Economics and Statistics, Department of Agriculture and Cooperation, 2012-13.

DRMR, 2011. Vision 2030. Directorate of Rapeseed-Mustard Research, Bharatpur, 321303 Rajasthan, Pp30.

Frommer, W.B., and Von Wiren, N., 2002. Plant biology Ping Pong with boron. Nature, 420(6913), 282-283.

Goldbach, H.E., Q. Yu., Wingender, R., Schulz, M., Wimmer, M., Findeklee, P., Baluska, F., 2001. Rapid response reactions of roots top boron deprivation. Journal of Plant Nutrition \& Soil Science, 164, 173-181.

Hassan, A.M., and Malhi, S.S., 2011. Phenology and seed quality response of rape (B. napus) versus mustard ( $B$. juncea) to sulphur and potassium fertilization in northwest Pakistan. Journal of Plant Nutrition, 34(8), 11751185.

Hossain, M.A., Jahiruddin, M., Khatun, F., 2011. Effect of boron on yield and mineral nutrition of mustard (Brassica compestris). Bangladesh Journal of Agriculture Research.

Islam, M.B. 2005. Requirement of boron for mustard, wheat and chickpea based rice cropping patterns. Ph.D. Dissertation, Department of Soil Science, Bangladesh Agriculture University Mymensingh.

Jamal, A., Fazli, I.S., Ahmad, S., Abdin, 
M.Z., 2006. Interactive effect of nitrogen and sulphur on yield and quality of groundnut (Arachis hypogea L.). Korean Journal of Crop Science. 51, 519-522.

Jat, S., Nath, T., Kumar, D., and Kashiwar, S., 2017, Response of Sulphur nutrition and mulching in Indian mustard (Brassica napes L.), International Journal of Plant and Soil Science, 19 (6), 1-11.

Kumar, R., Singh, V.Y., Singh, S., Latare, M.A., Mishra, P.K., Supriya, 2012. Effect of phosphorus and sulphur nutrition on yield attributes, yield of mungbean (Vigna radiata). Jouranl of Chemical and Pharmaceutical Research, 4 (5), 2571-2573.

Malhi, S.S., and Leach, D.D., 2002. Optimizing yield and quality of canola seed with balanced fertilization in the Parkland Zone of the Western Canada (cited 2014 Dec 21). Available at:// www.usak.ca/ soils and crops/ conference-proceedings/previous-years/ Files/2002/2002-DOCS/Malhi \% 283\%29-2002.pdf.

Marschner, H., 2012. Marschner's mineral nutrition of higher plants. 3rd ed. Australia: Elsevier Ltd.

Morris, R.J., 2006. Sulphur in agriculture: Intrnational perspective. In: Proc. TSI FAI-IFA Symposium- cum-Workshop on Sulphur in Balanced Fertilization, held at New Delhi, India. Pp.1-8.

Nagaraj, G., 1995. A Text Book of "Quality and Utility of Oilseeds" by Published by The Project Director, Directorate of Oilseed Research, Rajendranagar, Hyderabad, 500030.

NIIR, Board. "Hand book on Herb Cultivation and Processing" Publised by Asia Pacific Business Press Inc. Regd. Office: 106 - E Kamala Nagar, Delhi 110007 (India). Page 90.

O’Neill, M.A., Ishii, T., Albersheim, P., Darvill, A.G., 2004. Rhmnogalacturonm
II: structure and function of borate cross linked cell wall pectic polysaccharide. Annual Review Plant Biology, 55, 109139.

Orlovius, K., Kirkby, E.A., 2013. Fertilizing for high yield and quality oilseed rape. IPI Bulletin No. 16, International Potash Institute.

Pavani, S., Bhanu Rekha, K., Sudhakara Babu, S.N., Madhu Moguloju, 2013. Effect of nitrogen and sulphur on growth, yield and quality of sunflower (Helianthus annus L.) Crop Research 45 (1, 2 \&3), 152-154.

Rana, K.S., Rana, D.S., Gautam, R.C., 2004. Influence of phosphorus, sulphur and boron on growth, yield, nutrient uptake and economics of Indian mustard (Brassica juncea) under rainfed conditions, Indian Journal of Agronomy 50(4), 314-316.

Rashid, M.H., Hasan, M.M., Ahamad, M., Rahaman, M.T., Rahaman, K.A.M.M., 2012. Response of mustard to boron fertilization, Bangladesh Journal of Agriculture Research, 37(4), 677-682.

Saha, P.K., Saleque, M.A., Zaman, S.K., Bhujiyan, N.J., 2003. Response of mustard to $\mathrm{S}, \mathrm{Zn}$ and $\mathrm{B}$ in calcareous soil. Bangladesh Journal of Agriculture Research, 28(4), 633-636.

Sakal, R., Singh, A.P., Choudhary, B.C., Shahi, B., 2001. Sulphur status of Usifluvents and response of crops to sulphur application. Fertilizer News 46, 61-65.

Sarkees, N.A., 2013. Response of growth, yield and oil of rapseed to sowing method and seeding rate. Journal of Agriculture and Veterinary Science, Volume 3, Issue 1, PP 01-06.

Sheoran, P., Sheoran, O.P., Sardana, V., 2013. Modeling sunflower productivity and profitability in relation to adequate and limited sulphur availability under semiarid irrigated condition. 
International Journal of Agronomy, 2013 (2013), article ID 738263, 4 pages http://dx.doi.org/10.1155/2013/738263.

Tomar, S.K., and Singh, K., 2007. Response of Indian mustard (Brassica juncea L.) to nitrogen and sulphur fertilization under rainfed condition of diaraland. International Journal of Agriculture Science 3(2), 5-9.

Tomar, S.K., Singh, K., 2007. Response of Indian mustard (Brassica juncea L.) to nitrogen and sulphur fertilization under rainfed condition of diaraland. International Journal of Agriculture
Science 3(2), 5-9.

Verma, C.K., Prasad, K., Yadav, D.D., 2012. Studies on response of sulphur, zinc and boron levels on yield, economics and nutrients uptake of mustard (Brassica juncea (L.) Czern \& Coss.) Crop Research (Hisar), 44(1/2), 75-78.

Verma, S.K., Singh, S.K., Singh, T.K., 2011. Effect of nitrogen and sulphur on growth, yield and nutrient uptake by Indian mustard (Brassica juncea) under rainfed condition. Indian Journal of Agricultural Sciences, 81(2), 145-149.

\section{How to cite this article:}

Hemkalyan Verma and Joy Dawson. 2018. Yield and Economics of Mustard (Brassica compestris L.) as Influenced by Sowing Methods and Levels of Sulphur and Boron. Int.J.Curr.Microbiol.App.Sci. 7(01): 380-386. doi: https://doi.org/10.20546/ijcmas.2018.701.043 